\title{
Formulated Beta-Cyfluthrin Shows Wide Divergence in Toxicity among Bird Species
}

\author{
Laura M. Addy-Orduna, ${ }^{1}$ María-Elena Zaccagnini, ${ }^{2}$ Sonia B. Canavelli, ${ }^{1}$ and Pierre Mineau ${ }^{3}$ \\ ${ }^{1}$ Estación Experimental Agropecuaria Paraná, Instituto Nacional de Tecnología Agropecuaria (INTA), Ruta 11 km 12.5 , \\ Paraná, 3100 Entre Ríos, Argentina \\ ${ }^{2}$ Instituto de Recursos Biológicos, Instituto Nacional de Tecnología Agropecuaria (INTA), \\ Castelar, 1712 Buenos Aires, Argentina \\ ${ }^{3}$ Science and Technology Branch, Environment Canada, Ottawa, ON, Canada KIA OH3
}

Correspondence should be addressed to Laura M. Addy-Orduna, laddy@parana.inta.gov.ar

Received 9 August 2010; Revised 26 November 2010; Accepted 21 January 2011

Academic Editor: Virginia Moser

Copyright (c) 2011 Laura M. Addy-Orduna et al. This is an open access article distributed under the Creative Commons Attribution License, which permits unrestricted use, distribution, and reproduction in any medium, provided the original work is properly cited.

\begin{abstract}
It is generally assumed that the toxicity of pyrethroid insecticides to birds is negligible, though few species have been tested. The oral acute toxicity of formulated beta-cyfluthrin was determined for canaries (Serinus sp.), shiny cowbirds (Molothrus bonariensis), and eared doves (Zenaida auriculata). Single doses were administered to adults by gavage. Approximate lethal doses $50\left(\mathrm{LD}_{50}\right)$ and their confidence intervals were determined by approximate D-optimal design. Canaries were found to be substantially more sensitive to formulated beta-cyfluthrin $\left(\mathrm{LD}_{50}=(170 \pm 41) \mathrm{mg} / \mathrm{kg}\right)$ than the other two species tested $\left(\mathrm{LD}_{50}=(2234 \pm 544) \mathrm{mg} / \mathrm{kg}\right.$ and $\mathrm{LD}_{50}=(2271 \pm 433) \mathrm{mg} / \mathrm{kg}$, resp.). The $\mathrm{LD}_{50}$ obtained for canaries was also considerably lower than typical toxicity values available in the literature for pyrethroids. This study emphasizes the need for testing a broader range of species with potentially toxic insecticides, using modern up and down test designs with minimal numbers of birds.
\end{abstract}

\section{Introduction}

The widespread use of pesticides contributes to population declines and mortality of birds in agroecosystems [1]. Among the various categories of pesticides, insecticides typically present a higher risk of acute effects [2,3] because of their elevated inherent toxicities and high potential for exposure. Documented cases of mass mortality by intoxication and the various studies reporting negative effects of insecticides on birds are clear evidence of the risk posed by insecticides on wild bird species (e.g., [2-11]). One case of mass mortality of birds that received a great deal of attention in Argentina was the 1995-1996 mortality of Swainson's hawks caused by monocrotophos, an organophosphorus insecticide $[12,13]$. After this event, monocrotophos registration was cancelled in Argentina while the pyrethroid insecticides gained in importance and popularity.

Among insecticides, pyrethroids are a class of neurotoxic synthetic insecticides widely used due to their relative safety to mammals and birds, high insecticidal potency at low dosages, and fast biodegradation [14]. Insect axon sodium channels are 100-fold more sensitive to pyrethroid esters than mammalian channels [15]. For these reasons, pyrethroids have gradually replaced organochlorine, organophosphate, and carbamate insecticides in the field. Several studies about pyrethroids have been conducted on vertebrates (e.g., [1618]), the majority on rodents (e.g., [19-23]). The neurotoxicity of pyrethroids to mammals depends on the stereochemical configuration and the pyrethroid structure [24,25]. In contrast, little is known of the toxicity of pyrethroids to birds, probably because this class of insecticides is generally considered to have negligible toxicity to birds.

Beta-cyfluthrin(cyano-(4-fluoro-3-phenoxyphenil)-methyl-3-(2,2-dichloroethenyl)-2,2-dimethyl-cyclopropane carboxylate) is the active ingredient of insecticide formulations used to control a wide variety of pests on cotton, corn, sunflower and soybean crops. Like other pyrethroids, betacyfluthrin presents stereoselective interaction with a fraction 
of the sodium channels of the neuronal membranes, resulting in a prolongation of the inward sodium currents evoked in neurons by every incoming pulse of excitatory stimulation [26-28]. Beta-cyfluthrin is a mixture of four diastereomers, with diastereomers II and IV predominating and determining chemical and physical properties of the substance $[29,30]$. Beta-cyfluthrin is a type II pyrethroid, with a characteristic cyano group on the alpha carbon. Type II pyrethroids present greater insecticidal effectiveness and higher toxicity than type I pyrethroids. Type II esters keep the sodium channel open for a more prolonged time period than type I esters [31]. The main signs of intoxication of type II pyrethroids in mammals include choreoathetosis and salivation (CS) [25].

The reported $\mathrm{LD}_{50}$ of beta-cyfluthrin to birds in the Pesticide Manual [32] is $>2000 \mathrm{mg} / \mathrm{kg}$ in the Japanese quail. The USEPA in its "ECOTOX" database (http://cfpub.epa.gov/ ecotox/) gives the same value, but associated with the northern bobwhite. Yet, unpublished information cited in a report without details about vehicle or formulation gave an $\mathrm{LD}_{50}$ of ca. $100 \mathrm{mg} / \mathrm{kg}$ for beta-cyfluthrin in canaries as well as the more usual values for northern bobwhite and mallard duck of $>2000 \mathrm{mg} / \mathrm{kg}$ [29]. This value for canaries, if real, casts doubts on the general wisdom that pyrethroids are non-toxic to birds. The present study had for objective independent corroboration of the $\mathrm{LD}_{50}$ of betacyfluthrin to canaries and determining the acute oral toxicity of commercially formulated beta-cyfluthrin to two novel and wild species, the shiny cowbird (Molothrus bonariensis) and the eared dove (Zenaida auriculata).

\section{Materials and Methods}

2.1. Site and General Conditions of Study. The study was carried out in the research facilities of the INTA (Instituto Nacional de Tecnología Agropecuaria) at the Paraná Agricultural Experimental Station ( $\left.31^{\circ} 50^{\prime} 53^{\prime \prime} \mathrm{S}, 60^{\circ} 32^{\prime} 19^{\prime \prime} \mathrm{W}\right)$. The study was carried out in an aviary of $20 \times 10 \mathrm{~m}$, including an acclimation area with 6 groups of pens (each $3 \times 2 \times$ $3 \mathrm{~m})$ and 24 individual test cages (each $0.5 \times 0.5 \times 0.5 \mathrm{~m}$ ). The photoperiod and the average temperature of the testing room during the dosing were recorded (Tables 2 and 3 ). The ventilation was controlled so as to maintain the indoor conditions of temperature and humidity within outdoor environmental ranges.

2.2. Selection, Capture, and Housing of Birds. The wild birds, shiny cowbirds, and eared doves were selected based on their large numbers in surrounding fields, which assured their availability, abundance, and capture success. Shiny cowbirds were captured with mist-nets and eared doves with bait traps. Captive bred canaries were used. Healthy adult birds were weighted and grouped by sex before being acclimated to experimental conditions for at least 14 days. At least three $1.5 \mathrm{~m}$-perches were placed in each pen. Shiny cowbirds were fed insectivore certified commercial food, eared doves were offered a mix of wheat and sunflower seeds, and canaries, a commercial seed mix and ground egg. Bottled water for human consumption was offered ad libitum to all species. Because of the absence of a constituted animal care committee at INTA or at the local university (Universidad Nacional del Litoral) which provided academic supervision of this research, guidelines of the Denver Wildlife Research Center of the US Department of Agriculture were followed for the capturing, transportation, housing, care, euthanasia, and necropsy of the birds, in addition to other procedures of the study [33-45].

2.3. Chemical and Dose. To obtain the test doses (mg beta-cyfluthrin/ $\mathrm{kg}$ body weight), we used a commercial formulation (Bulldock of Bayer CropScience), a suspension of $12.5 \mathrm{~g}$ a.i. $/ 100 \mathrm{~mL}$ of unreported inert ingredients. We assumed label concentration was correctly reported and administered to birds the necessary volume of formulated product corresponding to the required dose of betacyfluthrin. It is known that pyrethroid toxicity may be greatly influenced by the dosing vehicle [46]. Because wild birds are exposed to formulated products, we opted to test the formulation without an additional vehicle where possible and with distilled water as a diluent for several doses for canaries (see dilutions in the footnotes of Table 3 ).

Doses were calculated according to standard equations for each stage of the approximate D-optimal design [47], in milligrams of a.i. per kilogram of body weight, as shown in Table 3. The dosing volumes were calculated based on individual body weights measured within 12 hours of dosing (Table 1). To prevent regurgitation, the higher dose volumes ( $>0.17 \mathrm{~mL}$ for canaries, $>0.45 \mathrm{~mL}$ for shiny cowbirds, and $>1.0 \mathrm{~mL}$ for eared doves) were split and administered in up to four aliquots separated by 15 minutes. This split administration of doses took place for all species in the limit test, one canary in the first stage of the full test and all shiny cowbirds and eared doves in all stages of the full test (Table 1). Dose volumes never exceeded $16 \mathrm{~mL} / \mathrm{kg}$ BW (body weight) in canaries, $27 \mathrm{~mL} / \mathrm{kg}$ BW in shiny cowbirds, and $26 \mathrm{~mL} / \mathrm{kg} \mathrm{BW}$ in eared doves. The formulated test chemical was given by gavage. The catheter was lubricated with Vaseline to diminish possible discomfort when introduced. Individuals that regurgitated part or all of a dose and who survived the dose were substituted for others due to the fact that regurgitation modifies the dose and prevents the correct approximation of the $\mathrm{LD}_{50}$ [48]. Forty-six percent of shiny cowbirds, $33 \%$ of eared doves and $16 \%$ of canaries regurgitated, despite being fasted before the dose.

2.4. Procedure. Acute oral toxicity tests were carried out following draft Guideline 223 of the Organisation for Economic Cooperation and Development [47]. This procedure minimizes the number of birds used and has extensive statistical validation.

First, five individuals of each species were treated with a limit dose of $2000 \mathrm{mg} / \mathrm{kg}$ of test chemical. Following any mortality at this limit dose, $\mathrm{LD}_{50}$ were estimated in sequential stages with the approximate D-optimal design (full test; Figure 1). In canaries, the first stage of the full test was carried out to confirm and improve the initial estimate of the canary $\mathrm{LD}_{50}(250 \mathrm{mg} / \mathrm{kg}$, based on the aforementioned literature 


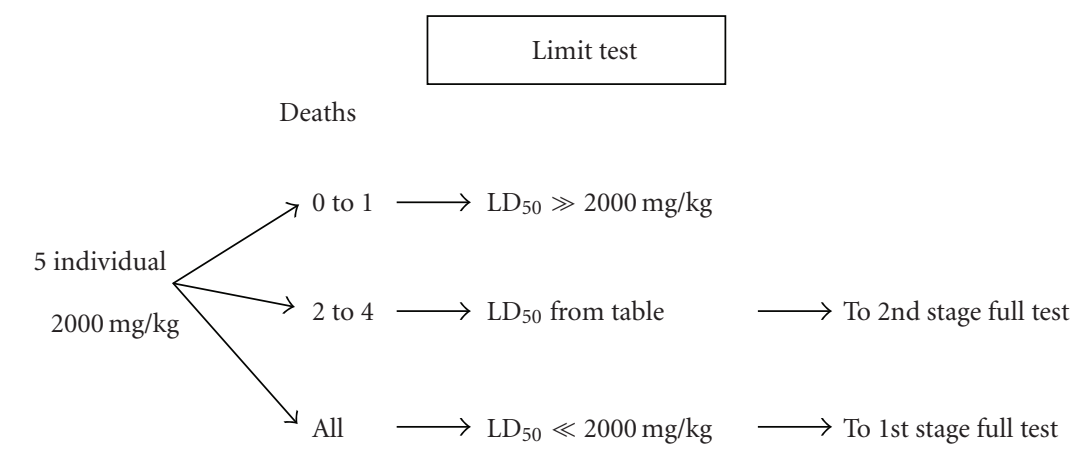

(a)

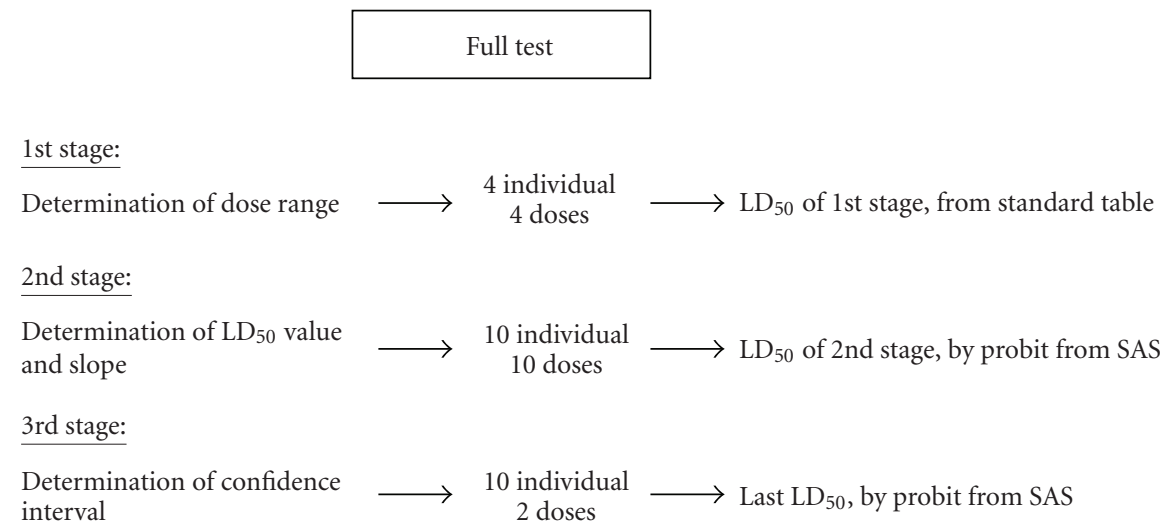

(b)

FIGURE 1: Diagram of methodology used.

value and the result of a limit test). An additional stage was added to obtain a greater level of precision.

Birds were randomly assigned to each test and were observed for 14 days after the dose. Mortality, clinical symptoms, change in weight between the beginning and the end of the study, regurgitations, time to death (in hours), and recovery were recorded.

Both test and control animals were examined by necropsy to determine macroscopic differences. The size, position and appearance of all organs and the full g.i. tract were examined. Also, livers and hearts were weighed and their relative weights calculated (1), in order to detect any pathology associated with any loss or increase in mass of these organs (hepatomegaly, necrosis, hypertrophy, etc.).

$$
\begin{aligned}
& R_{L}=\left(\frac{\text { liver weight }}{\text { body weight }}\right) * 100, \\
& R_{H}=\left(\frac{\text { heart weight }}{\text { body weight }}\right) * 100 .
\end{aligned}
$$

2.5. Statistical Analysis. We fit a probit model [49] to the combined data from all stages (STAT-SAS 6.1) to obtain the $\mathrm{LD}_{50}$ estimates, confidence intervals confidences and slopes of dose-response curves. Both the initial and final body weights and the relative weights of hearts and livers were compared by one-way ANOVA using SPSS v.10 for Windows.

\section{Results}

3.1. Limit Tests. Initial $\mathrm{LD}_{50}$ estimates obtained for the limit tests were $2247 \mathrm{mg} / \mathrm{kg}$ for both shiny cowbirds and eared doves because $40 \%$ of individuals died in both species. By contrast, all treated canaries died, and it was, therefore, impossible to obtain an initial estimate of $\mathrm{LD}_{50}$ with the limit test (Table 2).

3.2. Full Test. With canaries, the $\mathrm{LD}_{50}$ values estimated at each sequential stage were $68 \mathrm{mg} / \mathrm{kg}, 110 \mathrm{mg} / \mathrm{kg}$ and $170 \mathrm{mg} / \mathrm{kg}$, respectively. During the additional stage (similar to the third stage, performed in order to decrease the confidence intervals of the $\mathrm{LD}_{50}$ ), two of four individuals that received the highest dose regurgitated, and, for this reason, they were not included in the results. For shiny cowbirds and eared doves, although the doses administered in the second stage were the same because of similar results in the limit test, the mortality was different (Table 3 ). The $\mathrm{LD}_{50}$ estimates after the second stage were $1589 \mathrm{mg} / \mathrm{kg}$ and $2338.6 \mathrm{mg} / \mathrm{kg}$ for shiny cowbirds and eared doves, respectively. The final $\mathrm{LD}_{50}$ estimates, obtained by fitting a probit model to the combined data of all stages for each species were $170 \pm 41 \mathrm{mg} / \mathrm{kg}$ for canaries, $2234 \pm 544 \mathrm{mg} / \mathrm{kg}$ for shiny cowbirds, and $2271 \pm$ $433 \mathrm{mg} / \mathrm{kg}$ for eared doves. The dose-response curves are shown in Figure 2. 
TABLE 1: Dosing volumes (mL) and number of aliquots separately administered (in brackets).

\begin{tabular}{|c|c|c|c|c|c|c|c|c|c|c|}
\hline Individual & 1 & 2 & 3 & 4 & 5 & 6 & 7 & 8 & 9 & 10 \\
\hline \multicolumn{11}{|c|}{ Limit test } \\
\hline Canaries & $0.33[2]$ & $0.33[2]$ & $0.30[2]$ & $0.32[2]$ & $0.28[2]$ & & & & & \\
\hline Shiny cowbirds & $0.85[3]$ & $1.00[3]$ & $0.75[3]$ & $0.80[3]$ & $0.99[3]$ & & & & & \\
\hline Eared doves & $1.97[3]$ & $2.13[3]$ & $1.86[3]$ & $2.26[3]$ & $1.79[3]$ & & & & & \\
\hline \multicolumn{11}{|c|}{ 1st stage of the full test } \\
\hline Canaries & $0.12[1]$ & $0.13[1]$ & $0.16[1]$ & $0.24[2]$ & & & & & & \\
\hline \multicolumn{11}{|c|}{ 2nd stage of the full test } \\
\hline Canaries & $0.08[1]$ & $0.08[1]$ & $0.12[1]$ & $0.16[1]$ & $0.10[1]$ & $0.13[1]$ & $0.14[1]$ & $0.09[1]$ & $0.11[1]$ & $0.15[1]$ \\
\hline Shiny cowbirds & $0.31[2]$ & $0.36[2]$ & $0.48[2]$ & $0.5[3]$ & $0.68[3]$ & $0.67[3]$ & $0.81[3]$ & $0.82[3]$ & $1.5[4]$ & $1.34[4]$ \\
\hline Eared doves & $0.81[2]$ & $0.83[2]$ & $0.87[2]$ & $1.35[2]$ & $1.46[2]$ & $1.39[2]$ & $2.34[3]$ & $1.94[3]$ & $2.20[3]$ & $3.09[3]$ \\
\hline \multicolumn{11}{|c|}{ 3rd stage of full test } \\
\hline Canaries & $0.12[1]$ & $0.10[1]$ & $0.10[1]$ & $0.10[1]$ & $0.09[1]$ & $0.13[1]$ & $0.13[1]$ & $0.13[1]$ & $0.14[1]$ & $0.16[1]$ \\
\hline Shiny cowbirds & $0.45[2]$ & $0.45[2]$ & $0.44[2]$ & $0.35[2]$ & $0.35[2]$ & $1.26[3]$ & $1.00[3]$ & $1.00[3]$ & $1.03[3]$ & $1.07[3]$ \\
\hline Eared doves & $1.44[2]$ & $1.24[2]$ & $1.42[2]$ & $1.02[2]$ & $1.24[2]$ & $2.88[3]$ & $2.77[3]$ & $2.66[3]$ & $3.09[3]$ & $2.09[3]$ \\
\hline \multicolumn{11}{|c|}{ 3rd stage of the full test (2) } \\
\hline Canaries & $0.11[1]$ & $0.13[1]$ & $0.11[1]$ & $0.13[1]$ & $0.10[1]$ & $0.11[1]$ & $0.11[1]$ & $0.09[1]$ & & \\
\hline
\end{tabular}

TABLE 2: Mortality with $2000 \mathrm{mg} / \mathrm{kg}$ of test substance (limit test).

\begin{tabular}{lccccccc}
\hline Individual & 1 & 2 & 3 & 4 & 5 & $T\left({ }^{\circ} \mathrm{C}\right)$ & \multicolumn{1}{c}{} \\
\hline Canaries & $\mathrm{X}$ & $\mathrm{X}$ & $\mathrm{X}$ & $\mathrm{X}$ & $\mathrm{X}$ & 22.6 & 12.7 \\
Shiny cowbirds & $\mathrm{O}^{\dagger}$ & $\mathrm{O}$ & $\mathrm{O}^{\dagger}$ & $\mathrm{X}$ & $\mathrm{X}$ & 12.9 & 11.3 \\
Eared doves & $\mathrm{O}$ & $\mathrm{O}^{\dagger}$ & $\mathrm{X}$ & $\mathrm{X}$ & $\mathrm{O}$ & 19.7 \\
\hline
\end{tabular}

$\mathrm{X}$ : death; O: survival; ${ }^{\dagger}$ recovered from convulsions; $T$ : environmental average temperature during dosing; $P$ : photoperiod, in hours of light.

TABLE 3: Mortality in full test.

\begin{tabular}{|c|c|c|c|c|c|c|c|c|c|c|c|c|}
\hline Individual & 1 & 2 & 3 & 4 & 5 & 6 & 7 & 8 & 9 & 10 & $T\left({ }^{\circ} \mathrm{C}\right)$ & $P$ \\
\hline \multicolumn{13}{|c|}{ 1st stage } \\
\hline Dose $(\mathrm{mg} / \mathrm{kg})$ & $35.4^{\mathrm{a}}$ & $130.2^{\mathrm{d}}$ & $479.8^{g}$ & 1767.8 & & & & & & & & \\
\hline Canaries & $\mathrm{O}$ & $\mathrm{X}$ & $\mathrm{X}$ & $\mathrm{X}$ & & & & & & & 24.2 & 12.7 \\
\hline \multicolumn{13}{|c|}{ 2nd stage } \\
\hline Dose $(\mathrm{mg} / \mathrm{kg})$ & $23.2^{\mathrm{b}}$ & $29.5^{\mathrm{b}}$ & $37.4^{\mathrm{b}}$ & $47.5^{\mathrm{b}}$ & $60.2^{c}$ & $76.4^{\mathrm{c}}$ & $97.0^{c}$ & $123.0^{\mathrm{e}}$ & $156.1^{\mathrm{e}}$ & $198.0^{\mathrm{e}}$ & & \\
\hline Canaries & $\mathrm{O}^{*}$ & $\mathrm{O}^{*}$ & $\mathrm{O}^{*}$ & $\mathrm{O}^{*}$ & $\mathrm{O}$ & $\mathrm{O}$ & $\mathrm{O}^{\dagger}$ & $\mathrm{X}$ & $\mathrm{X}$ & $\mathrm{X}$ & 25.8 & 12.8 \\
\hline Dose $(\mathrm{mg} / \mathrm{kg})$ & 769.6 & 976.5 & 1065.7 & 1254.1 & 1475.7 & 1736.6 & 2043.5 & 2404.8 & 2829.8 & 3330.0 & & \\
\hline Shiny cowbirds & $\mathrm{O}^{*}$ & $\mathrm{O}^{*}$ & $\mathrm{O}$ & $\mathrm{X}$ & $\mathrm{O}$ & $\mathrm{O}$ & $\mathrm{X}$ & $\mathrm{X}$ & $\mathrm{X}$ & $\mathrm{X}$ & 15.1 & 11.0 \\
\hline Eared doves & $\mathrm{O}^{*}$ & $\mathrm{O}^{*}$ & $\mathrm{O}$ & $\mathrm{O}$ & $\mathrm{O}$ & $\mathrm{X}$ & $\mathrm{O}$ & $\mathrm{X}$ & $\mathrm{O}$ & $\mathrm{X}$ & 19.9 & 11.3 \\
\hline \multicolumn{13}{|c|}{ 3rd stage } \\
\hline Dose $(\mathrm{mg} / \mathrm{kg})$ & $68.3^{c}$ & $68.3^{c}$ & $68.3^{c}$ & $68.3^{c}$ & $68.3^{c}$ & $177.2^{\mathrm{e}}$ & $177.2^{\mathrm{e}}$ & $177.2^{\mathrm{e}}$ & $177.2^{\mathrm{e}}$ & $177.2^{\mathrm{e}}$ & & \\
\hline Canaries & $\mathrm{O}$ & $\mathrm{O}$ & $\mathrm{O}$ & $\mathrm{O}$ & $\mathrm{O}$ & $\mathrm{O}$ & $\mathrm{O}$ & $\mathrm{X}$ & $\mathrm{O}$ & $\mathrm{O}$ & 22.6 & 12.8 \\
\hline Dose (mg/kg) & 985.5 & 985.5 & 985.5 & 985.5 & 985.5 & 2558.9 & 2558.9 & 2558.9 & 2558.9 & 2558.9 & & \\
\hline Shiny cowbirds & $\mathrm{O}$ & $\mathrm{O}$ & $\mathrm{O}$ & $\mathrm{O}$ & $\mathrm{O}^{\dagger}$ & $\mathrm{O}$ & $\mathrm{X}$ & $\mathrm{O}^{\dagger}$ & $\mathrm{X}$ & $\mathrm{O}$ & 27.4 & 11.2 \\
\hline Dose (mg/kg) & 1451.0 & 1451.0 & 1451.0 & 1451.0 & 1451.0 & 3330.0 & 3330.0 & 3330.0 & 3330.0 & 3330.0 & & \\
\hline Eared doves & $\mathrm{O}$ & $\mathrm{O}$ & $\mathrm{O}$ & $\mathrm{O}$ & $\mathrm{O}$ & $\mathrm{X}$ & $\mathrm{X}$ & $\mathrm{X}$ & $\mathrm{X}$ & $\mathrm{X}$ & 21.5 & 12.0 \\
\hline \multicolumn{13}{|c|}{ 3rd stage (2) } \\
\hline Dose $(\mathrm{mg} / \mathrm{kg})$ & $105.5^{\mathrm{d}}$ & $105.5^{\mathrm{d}}$ & $105.5^{\mathrm{d}}$ & $105.5^{\mathrm{d}}$ & $273.9^{f}$ & $273.9^{\mathrm{f}}$ & $273.9^{f}$ & $273.9^{\mathrm{f}}$ & & & & \\
\hline Canaries & $\mathrm{O}$ & $\mathrm{O}$ & $\mathrm{O}$ & $\mathrm{O}$ & - & $\mathrm{X}$ & - & $\mathrm{X}$ & & & 19.9 & 12.9 \\
\hline
\end{tabular}

Dilutions: ${ }^{\mathrm{a}} 0.04,{ }^{\mathrm{b}} 0.05,{ }^{\mathrm{c}} 0.1,{ }^{\mathrm{d}} 0.15,{ }^{\mathrm{e}} 0.2,{ }^{\mathrm{f}} 0.4,{ }^{\mathrm{g}} 0.5 ;{ }^{*}$ without clinical signs of intoxication; X: death; $\mathrm{O}$ : survival; ${ }^{\dagger}$ recovered from convulsions; $T$ : environmental average temperature during dosing; $P$ : photoperiod, in hours of light. 


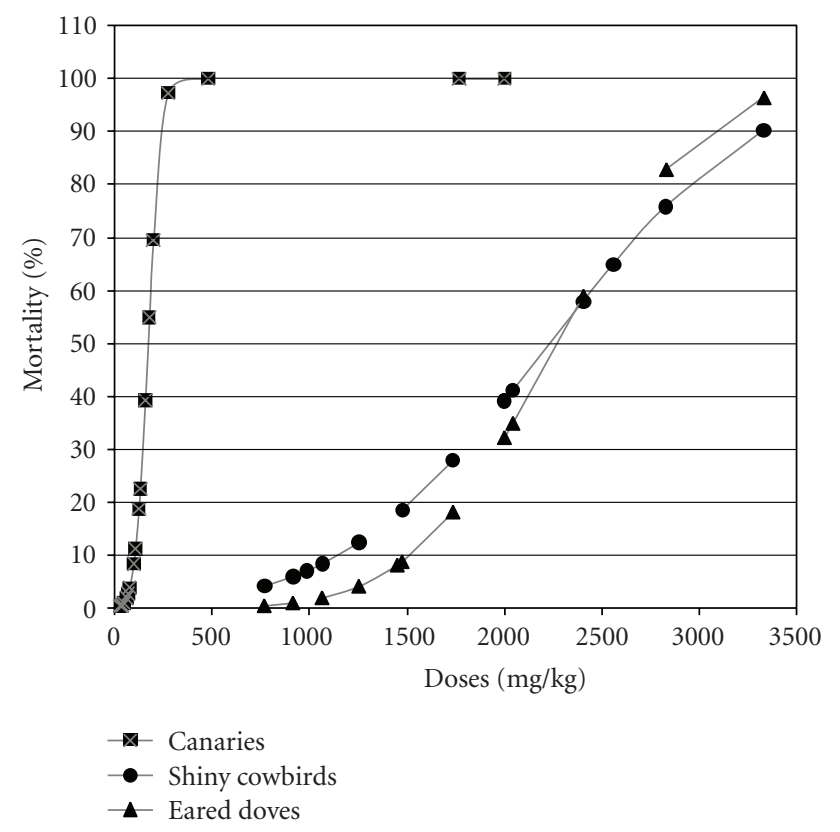

Figure 2: Dose-response curves.

Clinical signs included ruffled appearance, salivation (evidenced by constant deglutition movements and head shaking), decreased activity, prostration, panting, labored breathing, body tremor, balance loss and/or convulsions. Signs appeared shortly after dosing and lasted from a few minutes to a few hours. There were doses that did not produce clinical signs and others that allowed recuperation of individuals with signs of intoxication, including convulsions (Tables 2 and 3). All recuperations were within the first 24 hours after the dosage. Predose and 14-day postdose weights are given in Table 4. There were no significant differences between the body weights of the survivors before dosing and 14 days after the dose, except for canaries in the third stage of the full test where 14-day postdose weights were higher than predose weights $(P=.018)$. Maximum time to death was 1.75 hours in canaries, 3 hours in eared doves, and 5 hours in shiny cowbirds. Only canaries showed a tendency toward a shorter time to death with increasing dose (Figure 3).

All birds that died presented stiffness of fore and back limbs. We observed a white thick liquid in different sections of the g.i. tract, attributable to the insecticide formulation. Macroscopic differences among organs of treated and control individuals were not detected. Relative weights of heart and liver $\left(R_{L}\right.$ and $\left.R_{H}\right)$ did not vary either $(P>.05$ in all cases $)$.

\section{Discussion}

The $\mathrm{LD}_{50}$ value we obtained in canaries approximates the value presented in the report on beta-cyfluthrin of the European Commission [29], confirming it as moderately toxic or class II for this species. $\mathrm{LD}_{50}$ values for formulated betacyfluthrin obtained in shiny cowbirds (another passerine species) and eared doves, are close to the values reported for bobwhite quail and Japanese quail $[29,30]$, confirming beta-cyfluthrin to be practically non-toxic or class III for those species. Some care is needed before attributing these sensitivity differences solely to phylogeny. Variation in dosing procedures might have introduced unwanted variation in our results. These are discussed in detail below.

The different sensitivity to beta-cyfluthrin between canaries and other tested birds may be due to differences in the characteristics of the sites of toxic action, the intestinal absorption, the metabolism, and/or the elimination of this substance. For instance, the low acute toxicity of cypermethrin to quail had been explained by a high resistance of the CNS of quails to the lethal effects of cypermethrin, a greater extensive metabolism to a large number of products, and a rapid elimination in the excreta [50]. It is possible that similar physiological mechanisms occur in shiny cowbirds and eared doves, explaining their low susceptibility to betacyfluthrin. In addition, both significant differences in sensitivity at the sites of toxic action and metabolic differences and different main detoxification routes and enzymatic activities [51-59] may play a major role in the differential responses to these insecticides. On the other hand, differences in body size among the three bird species included in this study could have influenced the results. Based on allometric research carried out by Mineau et al. [60], the small body size of the canary compared to the other two species might have contributed to the higher sensitivity.

Factors related to the experimental setting and our procedures could have influenced the results of this study. A relationship between temperature and the toxic effects of pyrethroids has been shown for several groups of animals, including insects, amphibians and mammals [51, 61-64]. In our study, variations were noted in the ambient temperatures at the time of each stage of testing (Table 3). However, even when variation was slightly higher in the case of shiny cowbirds, it is unlikely to have influenced results because we obtained the $\mathrm{LD}_{50}$ through combined data from sequential stages with different temperatures. Additionally, the varying dose volumes and split administrations may have increased variability between experimental animals [61]. In our work canaries were administered a volume well below those used for the other two species (Table 1). Wolansky et al. [65] showed that increasing the amount of corn oil delivered with a dose of bifenthrin, another synthetic pyrethroid, changed the time course and potency of the pesticide in rats (a two-fold difference in potency was seen for a 5fold increase in corn oil). The use of oil as dosing agent should be avoided when highly lipophilic pesticides are being tested. We hope to have avoided this problem by dosing with the neat formulation where possible, and therefore not changing the relative concentration of pesticide in the dosing solution. Comparing the number of aliquots (Table 1) to the mortality in the tests (Table 3 ), suggests that the exact dosing regime probably did not affect our test results to any great extent. Finally, because we tested formulated material (with unknown inerts) rather than the active ingredient, we cannot ascertain definitively whether the canary is more sensitive to the active ingredient or to one of the formulants. However, the similarity to the value cited for the a.i. by the European Union and the relative lack of toxicity of the formulants 
TABLE 4: Body weights $( \pm 0.05 \mathrm{~g}$ for canaries, $\pm 0.1 \mathrm{~g}$ for shiny cowbirds and eared doves). Weights are given as predose weight- 14 -day postdose weight.

\begin{tabular}{|c|c|c|c|c|}
\hline Test & Individual & Canaries & Shiny cowbirds & Eared doves \\
\hline \multirow{5}{*}{ Limit test } & 1 & $20.65^{\mathrm{a}}$ & $53.0-47.4$ & $118.0-128.0$ \\
\hline & 2 & $20.35^{\mathrm{a}}$ & $62.2-54.2$ & $127.5-126.0$ \\
\hline & 3 & $18.45^{\mathrm{a}}$ & $46.8-39.6$ & $111.8^{\mathrm{a}}$ \\
\hline & 4 & $19.90^{\mathrm{a}}$ & $49.6^{\mathrm{a}}$ & $135.7^{\mathrm{a}}$ \\
\hline & 5 & $17.65^{\mathrm{a}}$ & $62.0^{\mathrm{a}}$ & $107.2-112.0$ \\
\hline \multirow{4}{*}{ 1st stage of the full test } & 1 & $17.40-21.00$ & & \\
\hline & 2 & $19.30^{\mathrm{a}}$ & & \\
\hline & 3 & $21.15^{\mathrm{a}}$ & & \\
\hline & 4 & $17.30^{\mathrm{a}}$ & & \\
\hline \multirow{10}{*}{ 2nd stage of the full test } & 1 & $22.75-21.95$ & $50.0-57.0$ & 131.6-130.0 \\
\hline & 2 & $17.85-19.85$ & $46.0-56.5$ & $105.9-115.0$ \\
\hline & 3 & $20.30-23.55$ & $56.1-61.0$ & $101.5-100.0$ \\
\hline & 4 & $21.40-24.60$ & $50.1^{\mathrm{a}}$ & $134.5-122.0$ \\
\hline & 5 & $20.15-21.00$ & $57.6-57.8$ & $124.0-122.0$ \\
\hline & 6 & $20.55-21.10$ & $48.0-52.8$ & $100.0^{\mathrm{a}}$ \\
\hline & 7 & $18.65-21.10$ & $49.4^{\mathrm{a}}$ & $143.0-133.3$ \\
\hline & 8 & $18.15^{\mathrm{a}}$ & $42.6^{\mathrm{a}}$ & $101.0^{\mathrm{a}}$ \\
\hline & 9 & $18.00^{\mathrm{a}}$ & $65.9^{\mathrm{a}}$ & $97.0-98.0$ \\
\hline & 10 & $19.40^{\mathrm{a}}$ & $50.3^{\mathrm{a}}$ & $116.0^{\mathrm{a}}$ \\
\hline \multirow{10}{*}{ 3rd stage of full test } & 1 & $21.60-22.35$ & $57.2-52.5$ & $124.0-128.0$ \\
\hline & 2 & $17.90-23.35$ & $57.0-52.0$ & $107.0-110.0$ \\
\hline & 3 & $18.60-21.00$ & $56.2-54.0$ & $122.0-123.0$ \\
\hline & 4 & $18.60-22.10$ & $45.0-44.0$ & $88.0-116.0$ \\
\hline & 5 & $17.10-18.85$ & $44.7-45.0$ & 107.0-106.0 \\
\hline & 6 & $17.85-18.60$ & $61.5-55.0$ & $108.0^{\mathrm{a}}$ \\
\hline & 7 & $18.25-20.80$ & $49.0^{\mathrm{a}}$ & $104.0^{\mathrm{a}}$ \\
\hline & 8 & $18.10^{\mathrm{a}}$ & $49.0-46.0$ & $100.0^{\mathrm{a}}$ \\
\hline & 9 & $20.35-27.35$ & $50.3^{\mathrm{a}}$ & $116.0^{\mathrm{a}}$ \\
\hline & 10 & $22.10-23.10$ & $52.4-50.0$ & $109.0^{\mathrm{a}}$ \\
\hline \multirow{6}{*}{ 3rd stage of the full test (2) } & 1 & $19.95-23.35$ & & \\
\hline & 2 & $22.95-24.60$ & & \\
\hline & 3 & $20.40-23.00$ & & \\
\hline & 4 & $23.40-23.60$ & & \\
\hline & 6 & $20.40^{\mathrm{a}}$ & & \\
\hline & 8 & $16.15^{\mathrm{a}}$ & & \\
\hline
\end{tabular}

${ }^{\mathrm{a} B i r d}$ died; only predose weight given.

in the other two species (with $\mathrm{LD}_{50}$ values similar to those obtained in quail or mallard with the active ingredient alone) suggests differences in sensitivity to the pyrethroid and not to the inerts included in the formulated material.

Clinical symptoms observed in response to high doses in the three species of bird are in agreement with those described by Sheets et al. [66] in rats treated with betacyfluthrin and those observed by Qadri et al. [67], who tested permethrin and cypermethrin in chickens. These symptoms consisted of decreased activity, tremors in the whole body, salivation, agitated breathing, flattened posture, and choreoathetosis. Nervous intoxication symptoms were observed a short time after intake and lasted up to a few hours, indicating that the removal of pyrethroids from the nervous system is rapid [68]. The survivors from all species did not show loss of body weight, at least by the end of the 14-day observation period (Table 4). Moreover, the body weights of canaries increased significantly during the third stage of the full test. Singh et al [69] observed increased body weights after acute treatment with beta-cyfluthrin on Albino rats. These authors postulate that the increase in body weight may be due to excessive food and water intake and increased food conversion efficiency of treated groups as compared to controlled ones.

All deaths occurred within 24 hours after the dose, probably because peak levels in blood, liver, muscle and brain are reached the first day of treatment $[25,70]$. Times to death in shiny cowbirds and eared doves were quite similar 


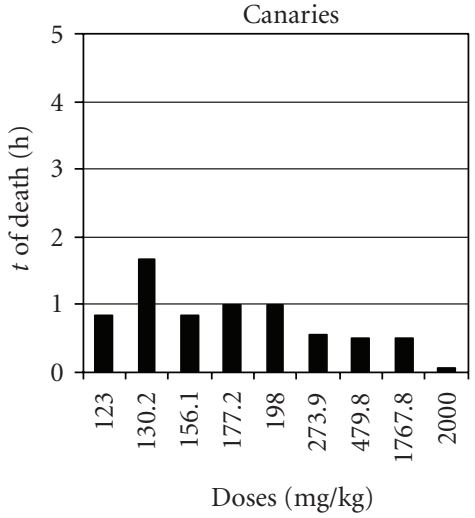

(a)

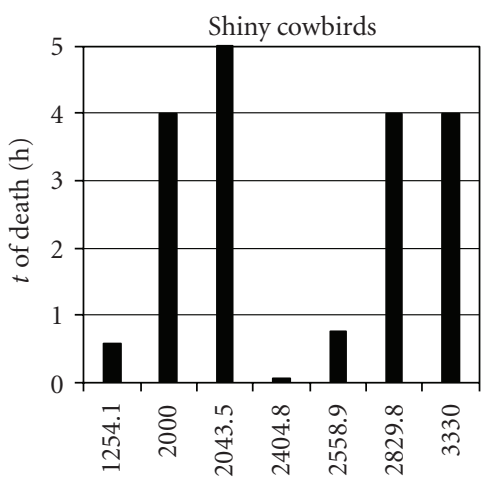

Doses $(\mathrm{mg} / \mathrm{kg})$

(b)

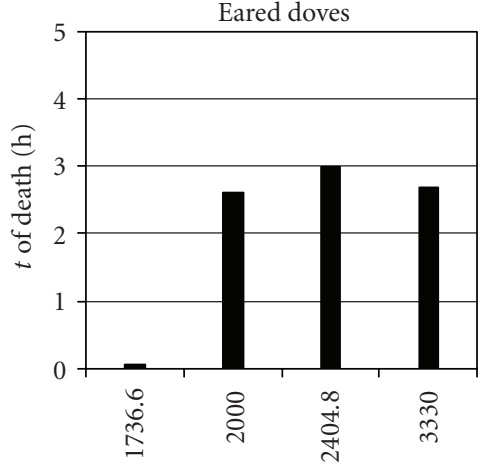

Doses $(\mathrm{mg} / \mathrm{kg})$

(c)

Figure 3: Time of death as a function of dose (only the doses that caused death are shown).

to those obtained with fenvalerate by Mumtaz and Menzer [71] in Japanese quail (4 to 8 hours). Rapid recovery is a characteristic of poisoning with pyrethroids in mammals [72]. In the three bird species, even individuals given doses approaching the $\mathrm{LD}_{50}$ recovered quickly (Table 3 ). Pascual et al. [48] reported a high frequency of regurgitation in doves as did we. Regurgitations were not as frequent in canaries, suggesting differences in their physiological capacity to regurgitate. Since the individuals that regurgitated were substituted for others, the results were not influenced by regurgitation in this study.

Acute and subacute studies have shown that pyrethroids at high doses cause liver hypertrophy, and, if death does not occur, these changes have been shown to be reversible [72, 73]. Nevertheless and as in Yavasoglu et al. [74], who worked with cypermethrin in rats, relative liver weights $\left(R_{L}\right)$-as an indirect measure of changes in liver health or functiondid not show any effect of dose. Although there are in vitro studies regarding the effects of pyrethroids on the cardiac muscle of rats and guinea pig [75-77], effects associated with loss or increase of heart mass were not detected here.

In conclusion, although there were factors that possibly exacerbated the differences of susceptibility within or between species (e.g., varying dose volumes, multiple dosing scheme, variable ambient temperatures, body size, etc.), the high sensitivity of canaries to beta-cyfluthrin was corroborated. On the other hand, formulated beta-cyfluthrin was found to be practically non-toxic to shiny cowbirds and eared doves. These results emphasize the need to test a broader range of species before generalizing about the toxicity of pyrethroids (and possibly other pesticides) to birds. In the case of beta-cyfluthrin specifically, although low application rates are generally used in the field (7.5-20 g a.i./ha according to Tomlin [32]), it is necessary to consider the potential variation in the toxicity of this pesticide in order to fully assess its safety to birds. In the present case, a species sensitivity approach [78] would suggest that other species of birds, especially small bodied species, will show higher sensitivity to pyrethroids. Future research is needed to explain why the canaries are more sensitive to beta-cyfluthrin, to determine whether canaries are similarly more sensitive to other pyrethroids, and more importantly, whether wildlife species related phylogenetically to canaries also present a high sensitivity to pyrethroids.

\section{Acknowledgments}

The authors thank Environment Canada and Instituto Nacional de Tecnología Agropecuaria (INTA) that financed and supported this paper. Also, They thank Dr. Brian Collins for his essential statistical collaboration; Dr. Julie Brodeur for her review, INTA staff, and Natalia Bossel who collaborated on captures and provision of materials; Juan Carlos Reboreda, for his valuable contribution on shiny cowbird husbandry; both directors of the EEA-Paraná as the Entre Ríos Regional Center, who supported this work in the Experimental Station of Paraná; finally two anonymous referees who provided useful comments on earlier drafts.

\section{References}

[1] L. J. Blus and C. J. Henny, "Field studies on pesticides and birds: unexpected and unique relations," Ecological Applications, vol. 7, no. 4, pp. 1125-1132, 1997.

[2] R. Guitart, M. Sachana, F. Caloni, S. Croubels, V. Vandenbroucke, and P. Berny, "Animal poisoning in Europe. Part 3: wildlife,” Veterinary Journal, vol. 183, no. 3, pp. 260-265, 2010.

[3] M. Hernández and A. Margalida, "Pesticide abuse in Europe: effects on the Cinereous vulture (Aegypius monachus) population in Spain," Ecotoxicology, vol. 17, no. 4, pp. 264-272, 2008.

[4] M. A. Fleischli, J. C. Franson, N. J. Thomas, D. L. Finley, and W. Riley, "Avian mortality events in the United States caused by anticholinesterase pesticides: a retrospective summary of National Wildlife Health Center records from 1980 to 2000," Archives of Environmental Contamination and Toxicology, vol. 46, no. 4, pp. 542-550, 2004.

[5] P. Mineau, M. R. Fletcher, L. C. Glazer et al., "Poisoning of raptors with organophosphorous and carbamates pesticides with emphasis on Canada, U.S. and U.K.," The Journal of Raptor Research, vol. 33, no. 1, pp. 1-37, 1999. 
[6] D. R. Dietrich, P. Schmid, U. Zweifel et al., "Mortality of birds of prey following field application of granular carbofuran: a case study," Archives of Environmental Contamination and Toxicology, vol. 29, no. 1, pp. 140-145, 1995.

[7] E. Martínez-López, D. Romero, P. María-Mojica, J. E. Martínez, J. F. Calvo, and A. J. García-Fernández, "Changes in blood pesticide levels in booted eagle (Hieraaetus pennatus) associated with agricultural land practices," Ecotoxicology and Environmental Safety, vol. 72, no. 1, pp. 45-50, 2009.

[8] J. E. Elliott, L. K. Wilson, K. M. Langelier, P. Mineau, and P. H. Sinclair, "Secondary poisoning of birds of prey by the organophosphorus insecticide, phorate," Ecotoxicology, vol. 6, no. 4, pp. 219-231, 1997.

[9] M. Martínez-Haro, R. Mateo, R. Guitart et al., "Relationship of the toxicity of pesticide formulations and their commercial restrictions with the frequency of animal poisonings," Ecotoxicology and Environmental Safety, vol. 69, no. 3, pp. 396-402, 2008.

[10] C. H. Walker, "Neurotoxic pesticides and behavioural effects upon birds," Ecotoxicology, vol. 12, no. 1-4, pp. 307-316, 2003.

[11] J. E. Elliott, M. J. Miller, and L. K. Wilson, "Assessing breeding potential of peregrine falcons based on chlorinated hydrocarbon concentrations in prey," Environmental Pollution, vol. 134, no. 2, pp. 353-361, 2005.

[12] S. B. Canavelli and M. E. Zaccagnini, "Mortandad de aguilucho langostero (Buteo swainsoni) en la región pampeana: primera aproximación al problema," Tech. Rep., Instituto Nacional de Tecnología Agropecuaria, Buenos Aires, Argentina, 1996.

[13] M. I. Goldstein, T. E. Lacher, B. Woodbridge et al., "Monocrotophos-induced mass mortality of Swainson's hawks in Argentina, 1995-96," Ecotoxicology, vol. 8, no. 3, pp. 201-214, 1999.

[14] World Health Organization, Safety of Pyretroids for Public Health Use, World Health Organization, Geneva, Switzerland, 2005, Report no. WHO/CDS/WHOPES/GCDPP/2005.10.

[15] D. J. Ecobichon, "Toxic effects of pesticides," in Casarett \& Doull's Toxicology: The Basic Science of Poisons, C. D. Klaassen, Ed., pp. 763-809, McGraw-Hill, New York, NY, USA, 6th edition, 2001.

[16] M. Berrill, S. Bertram, A. Wilson, S. Louis, D. Brigham, and C. Stromberg, "Lethal and sublethal impacts of pyrethroid insecticides on amphibian embryos and tadpoles," Environmental Toxicology and Chemistry, vol. 12, no. 3, pp. 525-539, 1993.

[17] M. Z. Khan, "Effect of agricultural chemicals on reptiles: comparison of pyrethroid and organophosphate with phytopesticide on cholinesterase activity," Pakistan Journal of Biological Science, vol. 6, no. 9, pp. 821-825, 2003.

[18] A. C. K. Benli, "Investigation of acute toxicity of cyfluthrin on tilapia fry (Oreochromis niloticus L. 1758)," Environmental Toxicology and Pharmacology, vol. 20, no. 2, pp. 279-282, 2005.

[19] T. H. Hijzen and J. F. Slangen, "Effect of type I and type II pyrethroids on the startle response in rats," Toxicology Letters, vol. 40, no. 2, pp. 141-152, 1988.

[20] R. Gabbianelli, C. Nasuti, G. Falcioni, and F. Cantalamessa, "Lymphocyte DNA damage in rats exposed to pyrethroids: effect of supplementation with Vitamins E and C," Toxicology, vol. 203, no. 1-3, pp. 17-26, 2004.

[21] A. Çelik, B. Mazmanci, Y. Çamlica, U. Çömelekoglu, and A. Aşkin, "Evaluation of cytogenetic effects of lambdacyhalothrin on Wistar rat bone marrow by gavage administration," Ecotoxicology and Environmental Safety, vol. 61, no. 1, pp. 128-133, 2005.
[22] M. J. Wolansky, C. Gennings, and K. M. Crofton, "Relative potencies for acute effects of pyrethroids on motor function in rats," Toxicological Sciences, vol. 89, no. 1, pp. 271-277, 2006.

[23] K. Malkiewicz, M. Koteras, R. Folkesson et al., "Cypermethrin alters glial fibrillary acidic protein levels in the rat brain," Environmental Toxicology and Pharmacology, vol. 21, no. 1, pp. 51-55, 2006.

[24] L. J. Lawrence and J. E. Casida, "Pyrethroid toxicology: mouse intracerebral structure-toxicity relationships," Pesticide Biochemistry and Physiology, vol. 18, no. 1, pp. 9-14, 1982.

[25] D. M. Soderlund, J. M. Clark, L. P. Sheets et al., "Mechanisms of pyrethroid neurotoxicity: implications for cumulative risk assessment," Toxicology, vol. 171, no. 1, pp. 3-59, 2002.

[26] H. P. M. Vijverberg and J. Van den Bercken, "Neurotoxicological effects and the mode of action of pyrethroid insecticides," Critical Reviews in Toxicology, vol. 21, no. 2, pp. 105-126, 1990.

[27] T. Narahashi, "Neuronal ion channels as the target site of insecticides," Pharmacology and Toxicology, vol. 79, no. 1, pp. 1-14, 1996.

[28] C. H. Walker, S. P. Hopkin, R. M. Sibly, and D. B. Peakall, Principles of Ecotoxicology, Taylor \& Francis, London, UK, 1997.

[29] European Commission-Health \& Consumer Protection Directorate General, "Review report for the active substance beta-cyfluthrin," 6841/VI/97-final, December, 2002, http:// www.fluoridealert.org/pesticides/cyfluthrin.beta.eu.dec.2002 .pdf.

[30] Food and Agricultural Organization of the United Nations (FAO), "FAO specifications and evaluations for plant protection products, Beta-cyfluthrin," 1999, http://www.fao.org/ ag/AGP/AGPP/Pesticid/Specs/docs/Pdf/new/beta_cyf.pdf.

[31] R. M. Joy, "Pyrethrins and pyrethroid insecticides," in Pesticides and Neurological Diseases, D. J. Ecobichon and R. M. Joy, Eds., pp. 291-312, CRC, Boca Raton, Fla, USA, 2nd edition, 1994.

[32] C. D. S. Tomlin, The e-Pesticide Manual Version 4.2, a World Compendium, British Crop Protection Council, Hampshire, UK, 2009.

[33] NN, "Pigeon maintenance," WRC-296 R1, Guidelines of the Denver Wildlife Research Center of the US Department of Agriculture, Fort Collins, Colo, USA, 1993.

[34] J. R. Mason, “Oral gavage of passerine species,” WRC-265 R3, Guidelines of the Denver Wildlife Research Center of the US Department of Agriculture, Fort Collins, Colo, USA, 1996.

[35] M. L. Avery, "Necropsy of birds," AC/FL 005.00, Guidelines of the Denver Wildlife Research Center of the US Department of Agriculture, Fort Collins, Colo, USA, 1999.

[36] K. L. Roca, "Transfer, proper placement, and identification of animals," AC/FL 010.00, Guidelines of the Denver Wildlife Research Center of the US Department of Agriculture, Fort Collins, Colo, USA, 1999.

[37] K. L. Roca, “Animal care - General,” AC/FL 007.01, Guidelines of the Denver Wildlife Research Center of the US Department of Agriculture, Fort Collins, Colo, USA, 2000.

[38] K. L. Roca, "Blackbirds and starlings," AC/FL 009.01, Guidelines of the Denver Wildlife Research Center of the US Department of Agriculture, Fort Collins, Colo, USA, 2000.

[39] G. M. Linz, "Use of mist nets for capturing blackbirds," FP/ND 003.00, Guidelines of the Denver Wildlife Research Center of the US Department of Agriculture, Fort Collins, Colo, USA, 1999. 
[40] G. M. Linz, "Cervical dislocation as a humane means of killing captive birds," AC 001.00, Guidelines of the Denver Wildlife Research Center of the US Department of Agriculture, Fort Collins, Colo, USA, 1999.

[41] G. M. Linz, "Ground transport of red-winged blackbirds, yellow-headed blackbirds, common grackles, and birds of similar size," FP 005.00, Guidelines of the Denver Wildlife Research Center of the US Department of Agriculture, Fort Collins, Colo, USA, 1999.

[42] G. M. Linz, "Care of red-winged blackbird, yellow-headed blackbirds, common grackles, brown-headed cowbirds, and European starlings," AC/ND 001.00, Guidelines of the Denver Wildlife Research Center of the US Department of Agriculture, Fort Collins, Colo, USA, 2003.

[43] H. Martínez, "Blackbird maintenance (caged) in the ARB," AC/CO 032.00, Guidelines of the Denver Wildlife Research Center of the US Department of Agriculture, Fort Collins, CO 2005.

[44] N. Morrison, "Animal food storage at the ARB," AC/CO 017.00, Guidelines of the Denver Wildlife Research Center of the US Department of Agriculture, Fort Collins, Colo, USA, 2005.

[45] R. T. Sugihara, "Ordering, receiving, handling, storing, and disposal of chemicals and pesticides at the Hawaii Field Station," CH/HI 001.00, Guidelines of the Denver Wildlife Research Center of the US Department of Agriculture, Fort Collins, Colo, USA, 2005.

[46] K. M. Crofton, L. S. Kehn, and M. E. Gilbert, "Vehicle and route dependent effects of a pyrethroid insecticide, deltamethrin, on motor function in the rat," Neurotoxicology and Teratology, vol. 17, no. 4, pp. 489-495, 1995.

[47] Organisation for Economic Co-operation and Development (OECD), "Draft Test Guideline 223: avian acute oral toxicity test," in Proceedings of the 22nd Meeting of the Working Group of National Coordinators of the Test Guidelines Programme, Paris, France, 2010, ENV/JM/TG(2010)19.

[48] J. A. Pascual, A. D. M. Hart, and S. L. Fryday, "Incidence of lethal bird poisoning reduced by regurgitation of pesticidetreated food," Environmental Toxicology and Chemistry, vol. 18, no. 2, pp. 247-253, 1999.

[49] D. J. Finney, Probit Analysis, Cambrige University Press, Cambrige, UK, 3rd edition, 1971.

[50] R. Edwards, P. Millburn, and D. H. Hutson, "Comparative toxicity of cis-cypermethrin in rainbow trout, frog, mouse, and quail," Toxicology and Applied Pharmacology, vol. 84, no. 3, pp. 512-522, 1986.

[51] S. P. Bradbury and J. R. Coats, "Comparative toxicology of the pyrethroid insecticides," Reviews of Environmental Contamination and Toxicology, vol. 108, pp. 133-177, 1989.

[52] M. A. Sogorb and E. Vilanova, "Enzymes involved in the detoxification of organophosphorus, carbamate and pyrethroid insecticides through hydrolysis," Toxicology Letters, vol. 128, no. 1-3, pp. 215-228, 2002.

[53] J. L. Riviere, "Hepatic microsomal monooxygenase activities in natural populations of the Mallard Duck Anas platyrhynchos, the Tufted Duck Aythya fuligula and the Great Crested Grebe Podiceps cristatus," Ecotoxicology, vol. 1, no. 2, pp. 117135, 1992.

[54] C. H. Walker, "Avian forms of cytochrome P450," Comparative Biochemistry and Physiology C, vol. 121, no. 1-3, pp. 65-72, 1998.

[55] F. M. Bush, J. R. Price, and J. I. Townsend, "Avian hepatic esterases, pesticides and diet," Comparative Biochemistry and Physiology B, vol. 44, no. 4, pp. 1137-1151, 1973.
[56] H. M. Thompson, "Avian serum esterases: species and temporal variations and their possible consequences," ChemicoBiological Interactions, vol. 87, no. 1-3, pp. 329-338, 1993.

[57] M. C. Fossi, L. Lari, and S. Casini, "Interspecies variation of "B" esterases in birds: the influence of size and feeding habits," Archives of Environmental Contamination and Toxicology, vol. 31, no. 4, pp. 525-532, 1996.

[58] C. H. Walker and M. J. J. Ronis, "The monooxygenases of birds, reptiles and amphibians," Xenobiotica, vol. 19, no. 10, pp. 1111-1121, 1989.

[59] C. Roy, G. Grolleau, S. Chamoulaud, and J. L. Rivière, "Plasma B-esterase activities in European raptors," Journal of Wildlife Diseases, vol. 41, no. 1, pp. 184-208, 2005.

[60] P. Mineau, B. T. Collins, and A. Baril, "On the use of scaling factors to improve interspecies extrapolation of acute toxicity in birds," Regulatory Toxicology and Pharmacology, vol. 24, no. 1, pp. 24-29, 1996.

[61] M. J. Wolansky and J. A. Harrill, "Neurobehavioral toxicology of pyrethroid insecticides in adult animals: a critical review," Neurotoxicology and Teratology, vol. 30, no. 2, pp. 55-78, 2008.

[62] R. W. Wadleigh, P. G. Koehler, H. K. Preisler, R. S. Patterson, and J. L. Robertson, "Effect of temperature on the toxicities of ten pyrethroids to German cockroach (Dictyoptera: Blattellidae)," Journal of Economic Entomology, vol. 84, no. 5, pp. 1433-1436, 1991.

[63] B. Subramanyam and L. K. Cutkomp, "Influence of posttreatment temperature on toxicity of pyrethroids to five species of stored-product insects," Journal of Economic Entomology, vol. 80, no. 1, pp. 9-13, 1987.

[64] H. P. M. Vijverberg, G. S. F. Ruigt, and J. Van den Bercken, "Structure related effects of pyrethroid insecticides on the lateral line sense organ and on peripheral nerves of the clawed frog, Xenopus laevis," Pesticide Biochemistry and Physiology, vol. 18, no. 3, pp. 315-324, 1982.

[65] M. J. Wolansky, K. L. McDaniel, V. C. Moser, and K. M. Crofton, "Influence of dosing volume on the neurotoxicity of bifenthrin," Neurotoxicology and Teratology, vol. 29, no. 3, pp. 377-384, 2007.

[66] L. P. Sheets, R. G. Gilmore, and B. F. Hamilton, "An acute oral neurotoxicity screening study with technical grade FCR 4545 in Fischer 344 rats," Division Report No. 107755, Bayer Corporation Agriculture, 1997.

[67] S. S. H. Qadri, K. Jabeen, M. Mahboob, and M. Mustafa, "Haemotoxicity to chicken (Gallus gallus domesticus) by technical and formulation grades of some phosphoric and synthetic pyrethroid esters," Journal of Applied Toxicology, vol. 7, no. 6, pp. 367-371, 1987.

[68] W. N. Aldridge, "An assessment of the toxicological properties of pyrethroids and their neurotoxicity," Critical Reviews in Toxicology, vol. 21, no. 2, pp. 89-104, 1990.

[69] A. K. Singh, P. N. Saxena, and H. N. Sharma, "Stress induced by beta-cyfluthrin, a type-2 pyrethroid, on brain biochemistry of Albino rat (Rattus norvegicus)," Biology and Medicine, vol. 1, no. 2, pp. 74-86, 2009.

[70] K. B. Kim, S. S. Anand, H. J. Kim, C. A. White, and J. V. Bruckner, "Toxicokinetics and tissue distribution of deltamethrin in adult Sprague-Dawley rats," Toxicological Sciences, vol. 101, no. 2, pp. 197-205, 2008.

[71] M. M. Mumtaz and R. E. Menzer, "Comparative metabolism and fate of fenvalerate in Japanese quail (Coturnix coturnix japonica) and rats (Rattus norwegicus)," Journal of Agricultural and Food Chemistry, vol. 34, no. 6, pp. 929-936, 1986. 
[72] D. Mueller-Beilschmidt, "Toxicology and environmental fate of synthetic pyrethroids," Journal of Pesticide Reform, vol. 10, no. 3, pp. 32-39, 1990.

[73] J. Miyamoto, "Degradation, metabolism and toxicity of synthetic pyrethroids," Environmental Health Perspectives, vol. 14, pp. 15-28, 1976.

[74] A. Yavasoglu, F. Sayim, Y. Uyanikgil, M. Turgut, and N. Ü. Karabay-Yavasoglu, "The pyrethroid cypermethrin-induced biochemical and histological alterations in rat liver," Journal of Health Science, vol. 52, no. 6, pp. 774-780, 2006.

[75] P. J. Forshaw and J. E. Bradbury, "Pharmacological effects of pyrethroids on the cardiovascular system of the rat," European Journal of Pharmacology, vol. 91, no. 2-3, pp. 207-213, 1983.

[76] J. R. Berlin, T. Akera, T. M. Brody, and F. Matsumura, "The inotropic effects of a synthetic pyrethroid decamethrin on isolated guinea pig atrial muscle," European Journal of Pharmacology, vol. 98, no. 3-4, pp. 313-322, 1984.

[77] C. I. Spencer, K. H. Yuill, J. J. Borg, J. C. Hancox, and R. Z. Kozlowski, "Actions of pyrethroid insecticides on sodium currents, action potentials, and contractile rhythm in isolated mammalian ventricular myocytes and perfused hearts," Journal of Pharmacology and Experimental Therapeutics, vol. 298, no. 3, pp. 1067-1082, 2001.

[78] P. Mineau, A. Baril, B. T. Collins, J. Duffe, G. Joerman, and R. Luttik, "Pesticide acute toxicity reference values for birds," Reviews of Environmental Contamination and Toxicology, vol. 170, pp. 13-74, 2001. 

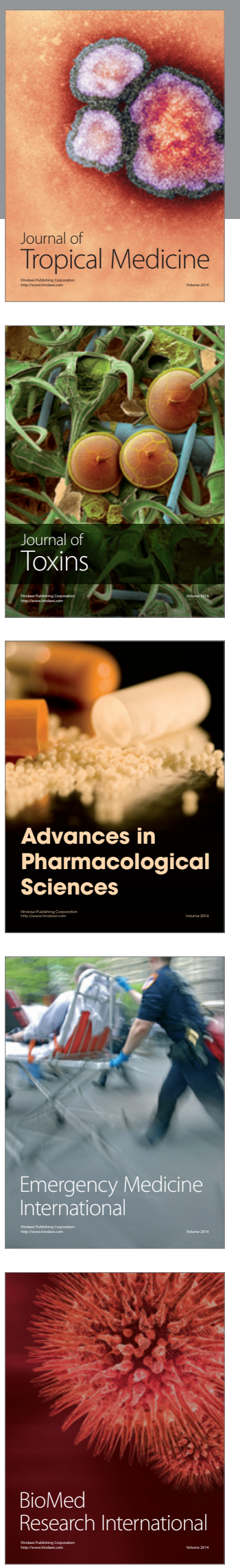
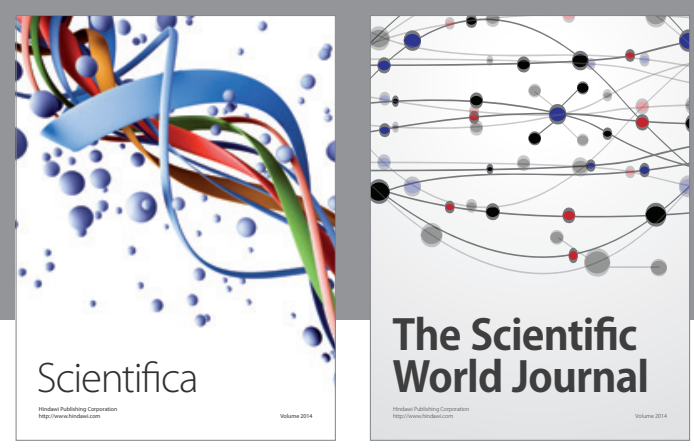

The Scientific World Journal
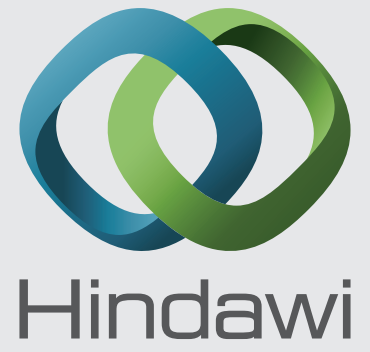

Submit your manuscripts at

http://www.hindawi.com
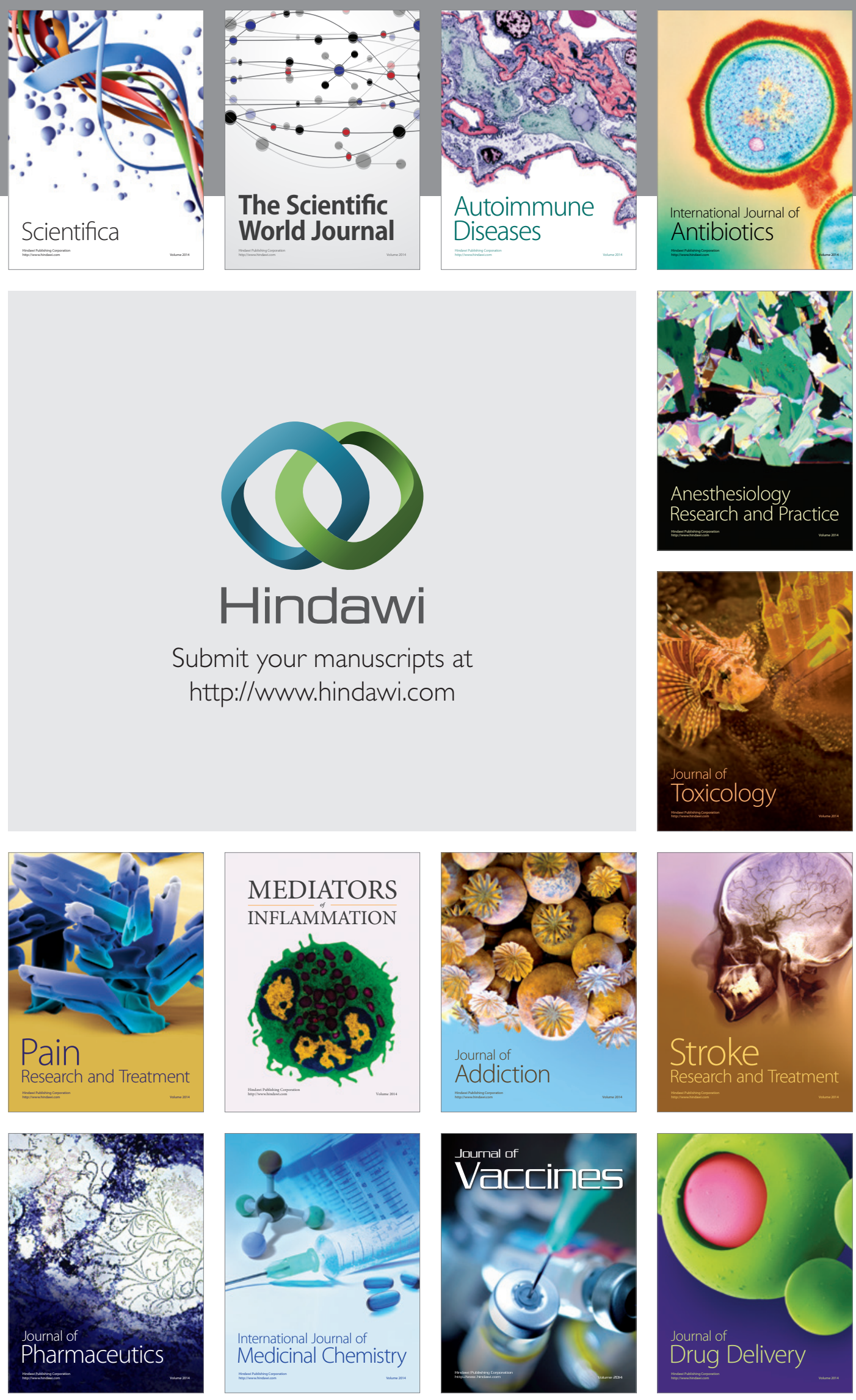